\title{
Antenatal classes as a form of preparation for parenthood: analysis of benefits of participating in prenatal education
}

\begin{abstract}
Prenatal education in the form of antenatal classes, referred to as School of Birth in Poland, aims at preparing both pregnant women and their partners for parenthood, on theoretical and practical basis. This is achieved by providing women with information on safe pregnancy, labor and puerperium, developing healthy behaviors and preparing parents to look after the newborn/ infant. The course program covers all psychophysical issues related to pregnancy, labor, puerperium and early stages of the child's life. The objective is to strengthen the health of mothers and children, alleviate pregnancy-related anxiety and fear, decrease the number of premature births and reduce the perinatal mortality rate. However, the scope of potential advantages of Schools of Birth depends not only on individual traits of the participants, but also on the engagement of professionals who teach the courses and the type of the school.
\end{abstract}

Keywords: antenatal classes, prenatal education, parenthood.

DOI: $10.1515 /$ pjph-2016-0040

\section{INTRODUCTION}

Prenatal education as an element of prenatal care is realised in Poland at the so-called Schools of Birth, a series of classes, which prepare both the mother and the father for labor and parenthood. The course program covers all psychophysical issues related to pregnancy, labor, puerperium and early stages of the child's life. Schools of Birth play a special role in primary prophylaxis and psychoeducation already in the pregnancy period $[1,2]$. Concern about professional education for pregnant women is expressed in the Regulation of the Minister of Health issued on the $20^{\text {th }}$ of September 2012 about the standards of medical management and procedures during provision of perinatal health care to women during physiological pregnancy, childbirth and the puerperium, and neonatal care (Journal of Laws, item 1100). In view of the regulation, it is recommended to prepare pregnant women for labor, postnatal period, breastfeeding and parenthood both in theory and practice, in groups or individually [3].

\section{SCHOOL OF BIRTH - THE IDEA, AIMS AND OBJEC- TIVES}

The notion of active preparation of women for labor dates back to the 1950s and 1960s. Initially, drawing from the ideas of G. Dick-Read, most attention was paid to psychoanalgesia, which is reducing anxiety to relieve muscle tension and thus alleviates pain. Dick-Read's theory assumes that the fear-tension-pain vicious circle may be broken by educating women on the physiology of labor and the course of childbirth. Having such knowledge lessens the anxiety and muscle tension thus reducing the pain experienced during labor. In Poland, the idea of Schools of Birth was popularized by Włodzimierz Fijałkowski. The concept which he introduced to antenatal classes for parents was to encourage pregnant women to cooperate with medical personnel by active relaxation and the so-called "natural perceptibility" $[1,2,4]$. Fijałkowski's ideas have been confirmed to be beneficial by a number of studies. For example, Stangret et al. demonstrated that anxiety in pregnant women who had not attended antenatal classes was much higher compared to women who had taken part in such courses [4].

Schools of Birth currently functioning in Poland were developed on the basis of Professor Fijałkowski's initial concept. Their popularity has been growing annually, with more than 400 schools registered in the country. The majority are private enterprises or courses held at hospital maternity wards. Antenatal classes are also organized by church communities, various societies and at fitness clubs $[5,6]$.

In a study by Kamińska et al., all the women surveyed believed that antenatal classes should be organized. They saw preparation for pregnancy and labor through prenatal education as necessary and important [7].

However, in another study by Małecka and Nowak, more than half of the surveyed women did not express any opinion as to whether a pregnant woman should prepare for delivery by attending antenatal classes. Research has also shown that as many as $27 \%$ of respondents did not participate in antenatal classes due to the fact that they "are unavailable" [8].

Well-conducted antenatal classes teach relaxation techniques, exercising and strengthening pelvic floor muscles or Kegel muscles and coping with pain by simple physical exercise and respiratory training. This practical part of the course pro- 
vides future parents with information on the so-called labor prophylaxis, whose main aim is to adequately oxygenate the child in subsequent weeks of pregnancy and during labor. Research shows that these techniques are also effective in reducing labor pain [9-11].

Schools of Birth emerged out of the need to alleviate pain during delivery. The great challenge that labor presents to women causes anxiety, which in turn leads to general body tension and pain. The fact that Schools of Birth educate women on aspects of their lives they are not familiar with and reduce anxiety and pain during labor speaks in favor of such courses. Educating women and their partners on pregnancy, labor and the postnatal period improves the well-being of a pregnant woman, who as a result endures physical suffering much better and has deeper understanding of the entire process $[2,12,13]$.

A number of studies from Poland and abroad demonstrate that antenatal classes and appointments with a midwife aim to reduce stress, alleviate the worries of expecting parents and prepare them to look after their child. The knowledge gained at such courses convinces a woman that she is capable of giving birth to her child in a natural way, without excessive physical suffering, using only non-pharmacological methods of alleviating labor pain [2,13-16].

Piziak's study results have shown that women attending antenatal classes were better prepared for pregnancy and labor, while better knowledge on the subject positively influenced their general mood. These women gave birth in a natural way more often than women who had not been prepared for delivery at antenatal classes [9].

Moreover, Consonni et al. demonstrated a positive correlation between low anxiety among pregnant women who attended prenatal courses and shorter hospitalization time of newborns [17].

However, a study by Chudobina et al. suggests that higher effectiveness of non-pharmacological methods of alleviating labor pain was related to higher education rather than participation in antenatal classes. As many as half of women who had attended antenatal classes did not know how to use these methods in practice. The study results indicate that Schools of Birth raise awareness on non-pharmacological methods of alleviating pain, however the ability of women to practically apply the techniques during labor is insufficient. There is a possibility that antenatal classes raise anxiety over labor, which may result in higher anxiety levels during delivery. The correlation between participation in antenatal classes and increased anxiety may stem from the fact that unprofessional video footage of labor is shown during antenatal classes. Such videos may raise fears of labor in pregnant women [18].

The original School of Birth project focused on the need to provide knowledge on the course of delivery, develop taskbased approach to childbirth and teach the ability of coping with pain. In the course of time the programs have evaluated and by now they encompass issues related to pregnancy, maternity and newborn/infant care. They also discuss the role of the father in the life of the child from the moment it is conceived. The task of present-day antenatal classes is to provide women and men with comprehensive knowledge to ensure the best possible parenthood $[2,19,20]$.

A holistic approach to pregnancy, labor and parenthood within Schools of Birth is possible due to engagement and cooperation of many specialists, midwives, obstetric gynaeco- logists, dieticians, physiotherapists and psychologists, who provide all the necessary information to ensure that pregnancy is a good experience for both the woman and her partner $[2,12,13]$.

Kozłowska et al. particularly stress the importance of antenatal classes conducted by a physiotherapist as they increase the effectiveness of the course and they are highly motivating for participants. According to these authors, it is important that a physiotherapist is present in the delivery room, stimulating behaviors previously learned by the woman [11].

Stangret et al. suggest that future research should compare anxiety levels among pregnant women depending on the teaching methods used in antenatal classes and the proportion of practical classes to theoretical classes [4]. In such courses conducted in Schools of Birth, theoretical knowledge is supplemented with practical activities, such as exercises which increase physical fitness and improve the well-being of the mother and the child during pregnancy, labor and in the postnatal period. Future parents are also familiarised with relaxation and breathing techniques, which may be used during pregnancy and labor. Exercise lowers the concentration of lactic acid in the serum, stimulates metabolism and prevents obesity and inconvenient constipations during pregnancy. It also lowers the probability of some gestational pathologies, such as varices, swelling, platypodia or leg cramps. Exercise has a positive effect on the mental attitude to delivery. Women who engage in exercise are less likely to choose anesthesia during labor and they better cooperate with the midwife [9-11].

Literature on the subject shows that appropriately chosen exercises, also included in programs offered by Schools of Birth, and physical activity during pregnancy help to prepare a woman for delivery [21-23].

One of the benefits of preparatory exercises is that they shorten the first stage of labor, help to better tolerate pain at that stage and reduce the incidence of perinatal injuries of the birth channel and the occurrence of perineotomy [5]. Kołomyjec et al. conducted a study which demonstrated that the duration of the first stage of delivery in primigravidas who attended antenatal classes was 18 minutes shorter, while the entire duration of labor was 12 minutes shorter compared to women who had not attended such classes [21]. Fabian et al. indicate in their research that the second stage of delivery was longer in patients who had participated in prenatal courses. This is explained by the fact that epidural anesthesia was given more frequently to patients who had attended antenatal classes [24]. Other conclusions can be found in the works of Laudański and Guzikowski who state that shorter duration of delivery and higher pain tolerance among women who attended School of Birth stem from their better knowledge on issues related to labor, visiting the delivery room as part of the classes and better cooperation with the assisting personnel. Lower percentage of perinatal injuries of the birth canal and lower rates of perineotomy among participants of the courses seems to confirm that participating in antenatal classes has a significant influence on the delivery $[25,26]$.

In the course of research on beneficial effects of exercise on pregnancy, it has also been noted that physical effort prevents depressed mood during pregnancy and puerperium, and accelerates recovery after childbirth [27,28]. What is of particular importance here is the mechanism of the exercise-depression relationship, which is based on psychological ("believing in yourself" and the distraction hypothesis) and biological theories (such as $\beta$-endorphins and thermogenic theory) $[29,30]$. 
Augustyniuk et al. stress that it is highly important that antenatal classes are attended by both parents. Participating in the course together strengthens the bond between partners and helps to develop good partner relationships. This, in turn, contributes to reducing labor-related anxiety. Antenatal classes are conducted by qualified staff, who teach how to cope with pregnancy complaints, how to alleviate labor pains and how the accompanying person may help during delivery $[31,32]$. That is why one of the main objectives of psychoprophylaxis in antenatal education is to teach appropriate behaviors during labor with special focus on the support given by the assisting person $[33,34]$.

According to many studies, the presence of an accompanying person/partner during antenatal classes and the labor itself offers great emotional and physical support to the woman. It significantly reduces anxiety during labor and lowers the incidence of postnatal complications [9,18,35-37].

According to Simkin et al. the presence of an accompanying person is correlated with shorter delivery time, lower doses of oxytocin administered and lower incidence of surgical labor interventions [38].

The literature published suggests that fathers who are present during childbirth should be familiarized with stages of delivery and prepared for the tasks they are expected to perform [39-43]. According to Sioma-Markowska et al. partners' attitudes during labor may differ dramatically, ranging from an active to a passive approach. Active approach involves tasks related to nursing and caring, control and instrumental action, and emotional support. The study found that a high percentage of fathers $(52.4 \%)$ participated in labor without preparation. This demonstrates that the idea of antenatal classes needs further promotion as an optimum and professional method of active participation in childbirth. It should be supplemented by other forms of education for fathers and further more comprehensive instruction provided in the delivery room [33].

An interesting study was presented by Kowalska et al. [27]. Their findings indicate that women who gave birth in the presence of their partners showed more severe depressive symptoms after childbirth in comparison with women giving birth in the traditional way. Despite the fact that the results are not statistically significant, they differ from reports by other authors. It is worth considering whether despite the fact that partners participated in antenatal classes their knowledge and attitudes indeed supported the mother and whether the decision about the father's assistance was made by both sides. This raises the question whether antenatal classes prepare the pregnant woman and the person who will assist her in labor equally well [27].

Similar observations have been made by BrzozowskaMagoń et al. In their study, $15 \%$ of women stated that the presence of their husbands during labor was not beneficial [44]. This is confirmed by Ćwiek at al. who quote mothers' comments such as "he was only a nuisance" or "he made me lose focus" $[41,45]$.

The authors who attempted to determine the partner's role during labor unanimously stress the fact that the only beneficial attitude is the active one, where the person accompanies and coaches the parturient $[33,34]$.

The educational program offered by Schools of Birth goes beyond providing knowledge on pregnancy and delivery. Care for the newborn is another important subject discussed in these classes. It is a crucial matter due to the fact that the birth of a child is an emotional, organisational and practical challenge for parents, who need to prepare to look after their offspring. Couples who are approached individually can consciously await their child in their own special way, overcoming fear, which is always experienced by expecting parents [6,9].

According to Grochans E. et al. appropriate know-ledge, skills and attitudes acquired by future parents during the time of pregnancy can significantly help them prepare for new responsibilities related to looking after the child [46].

In the study by Deluga et al., a vast majority of parents (96.4\%) believed that preparation for a birth of a child is necessary. As demonstrated by the studies discussed above, respondents who had attended Schools of Birth were better informed on basic issues related to looking after a newborn in comparison to people who did not take part in such classes. Moreover, the results show that women are becoming more aware of prenatal education offered by Schools of Birth or Mother Schools. Research suggests that these forms of training are chosen by more women in comparison with previous years [47]. Maciejewski J. et al. have also pointed to the positive role of antenatal courses which prepare future parents for looking after their child [42].

Yet another positive influence of antenatal classes on the awareness of parents is that they encourage positive health behaviors [48].

The time of awaiting a child, the birth and the postnatal period are extremely stressful events in a woman's life. Stress, according to Kossakowska-Petrycka and Walęcka-Matyja, is an important predictive factor for postnatal depressive disorders [49]. It has been observed that anxiety during pregnancy or childbirth over possible postnatal complications, physical pain and bad health condition of the child occurred most frequently in women who had not participated in antenatal classes [27]. This data complies with the results obtained by Walentyn et al. They observed that women who had attended antenatal classes felt much less anxiety over complications during labor and were more calm [50]. Similar results on the effect of classes at Schools of Birth have been reported by Kowalska et al. and Bączyk et al. in their studies on postpartum depression. They have noticed that stress levels during labor were lower in women who participated in courses preparing them for childbirth and motherhood. This resulted in fewer depressive symptoms in these women in the postnatal period [27,51]. Soet et al. also claim that theoretical preparation for childbirth effectively reduces anxiety and fear by increasing the woman's faith in her own abilities and skills [52].

However, some publications present a critical approach towards antenatal classes. For example, Sadowska et al. show in their study that many couples decide to participate in antenatal classes because they want to follow the example of other couples and/or follow trends (33.3\%); gaining know-ledge on childbirth was less frequently named (32.3\%) [53].

Cendrowska et al. consider antenatal classes a fashion, rather than a form of education. This kind of attitude towards prenatal courses could be changed by effective education on pregnancy and labor, which would include a practical component [19].

However, studies indicate an imbalance between theory and practice in programs of antenatal classes [54,55]. Research by Piziak and Spinelli et al. showed that the level of theoretical knowledge acquired in antenatal classes is usually higher than 
the ability to use it in practice. As a result, pregnant women do not realize how challenging a labor is and are not able to prepare for it in terms of physical efficiency, which increases maternal anxiety $[9,56]$. Kosińska et al. and Ćwiek also draw attention to this question. They emphasise that Schools of Birth often narrow their instruction on possible non-pharmacological methods of alleviating pain to massage of the lumbosacral area and taking squatting positions [36,57]. More optimistic observations have been made by Kołomyjec et al. In their study, as many as $75 \%$ of the respondents stated that the knowledge they acquired during antenatal classes was helpful and they translated it into practice during labor [21].

\section{CONCLUSIONS}

To conclude, it needs emphasizing that prenatal education is crucial for future parents and Schools of Birth are a source of professional knowledge shared by a number of specialists. Participating in antenatal classes is a valuable introduction to parenthood due to their numerous benefits in the perinatal period $[4,21,36,53]$. However, the scope of potential advantages of Schools of Birth depends not only on individual traits of the participants, but also on the engagement of professionals who teach the courses and the type of the school [21,24,53]. The knowledge and practical skills gained at antenatal classes reduce fears of future parents concerning pregnancy, labor and puerperium, and facilitate active and conscious participation in the delivery, care for the child and performing the role of a parent $[19,48]$.

\section{REFERENCES}

1. Iwanowicz-Palus G. Przygotowanie do porodu i rodzicielstwa - rola szkoły rodzenia. In: AM Bień, editor. Opieka nad kobietą ciężarną. Warszawa: Wydawnictwo Lekarskie PZWL; 2009. p.348-57.

2. Ćwiek D, Iwanowicz-Palus G, Stobnicka D. Szkoła Rodzenia. In: G.J. Iwanowicz-Palus (ed). Alternatywne metody opieki okołoporodowej. Warszawa: Wydawnictwo Lekarskie PZWL; 2012. p.109-21.

3. Rozporządzenie Ministra Zdrowia z dnia 20 września 2012 r. w sprawie standardów postępowania medycznego przy udzielaniu świadczeń zdrowotnych z zakresu opieki okołoporodowej sprawowanej nad kobietą w okresie fizjologicznej ciąży, fizjologicznego porodu, połogu oraz opieki nad noworodkiem (Dz.U. z $2012 \mathrm{Nr} 12$ poz. 1100).

4. Stangret A, Cendrowska A, Szukiewicz D. Kurs szkoły rodzenia jako sposób na obniżenie poziomu lęku przed porodem. Fam Med Prim Care Rev. 2009;11:53-9.

5. Kwiatek M, Gęca T, Biegaj-Fic J, Kwaśniewska A. Szkoła rodzenia - profil pacjentek oraz wpływ zajęć na przebieg porodu i stan noworodka. Med Og Nauk Zdr. 2011;17:111-5.

6. Preeti A. Nowoczesne zajęcia dla przyszłych rodziców. MPIP 2012;1/2:423.

7. Kamińska J, Mazurek M, Naworska B, Caus I, Kamiński B. Edukacja rodzinna. Zdr. Publ. 2002;112(Supl.1):30-3.

8. Małecka A, Nowak Z. Opinia badanych kobiet w ciąży dotycząca ważności uczestnictwa w szkole rodzenia jako formy przygotowania do porodu. Prz Lek. 2014;71:437-40.

9. Piziak W. Wpływ przygotowania psychofizycznego w szkole rodzenia na przebieg ciąży i porodu. Prz Med Uniw Rzesz. Rzeszów. 2009;3:282-92.

10. Kolanko AJ. Wybrane metody leczenia i efekty psychoprofilaktycznego przygotowania do porodu w szkołach rodzenia. Fizjoterapia. 1997;5:18-9.

11. Kozłowska J, Curyło M. Skutki przygotowania kobiet do porodu i połogu według zasad psychoprofilaktyki porodowej. Now Lek. 2005;74:159-62.

12. Sochocka L. Działalność szkół rodzenia. Pielęg Położna. 2000;10:20-1.

13. Białek A, Ćwiek D, Prociak J, Fryc D. Przygotowanie do porodu. In: D. Ćwiek (ed). Szkoła Rodzenia. Warszawa: Wydawnictwo Lekarskie PZWL; 2010. p.83-120.
14. Kłopocka-Rutka K. Kształtowanie postaw rodzicielskich oraz umacnianie więzi między partnerami-edukacyjna rola Szkoły Rodzenia. Pielęg XXI w. 2012;4:29-34.

15. Lowe NK. The nature of labor pain. Am J Obstet Gynecol. 2002;186(Suppl.5):S16-24.

16. Hodnett ED. Pain and women's satisfaction with the experience of childbirth: A systematic review. Am J Obstet Gynecol. 2002;186(Suppl.5):160-71.

17. Consonni EB, Calderon IM, Consonni M, et al. A multidisciplinary program of preparation for childbirth and motherhood: maternal anxiety and perinatal outcomes. Reprod Health. 2010;7:28. doi:10.1186/1742-4755-728.

18. Chudobina A, Woźniewski M, Mraz M. Wpływ szkoły rodzenia na praktyczne wykorzystywanie i skuteczność niefarmakologicznych metod łagodzenia bólu podczas porodu. Fizjoterapia. 2012;20:21-9.

19. Cendrowska A, Stangret A, Szukiewicz D. Wpływ szkoły rodzenia na subiektywną ocenę przygotowania teoretycznego i sprawnościowego. Nowa Med. 2008;15:2-6.

20. Fijałkowski W. Rozwinięty program szkoły rodzenia. MPIP. 1998;6:34-5.

21. Kołomyjec P, Suchocki S, Kędra-Rakoczy M. Wykształcenie i zachowania prozdrowotne ciężarnych biorących udział w zajęciach szkoły rodzenia oraz ich wpływ na przebieg porodu i stan noworodka. Klin Perinat Ginekol. 2007;43:57-60.

22. Karmowski A, Sobiech KA, Kotarska E, et al. Wpływ ćwiczeń ruchowych w szkole rodzenia na izoenzymatyczny wskaźnik dehydrogenazy mleczanowej w surowicy krwi rodzących. Adv Clin Exp Med. 2005;14:947-52.

23. Ćwiek D, Szczęsna M, Malinowski W, et al. Analiza aktywności fizycznej podejmowanej przez kobiety w czasie ciąży. Perinatol Neonatol Ginekol. 2012;5:51-4.

24. Fabian HM, Rådestad IJ, Waldenström U. Characteristics of Swedish women who do not attend childbirth and parenthood education classes during pregnancy. Midwifery. 2004;20:226-35.

25. Laudański T. Modyfikacja środowiska narodzin - potrzeby matki i dziecka a potrzeby nowoczesnego położnictwa. Ginekol Pol. 2001;72:668-73.

26. Guzikowski W. Psychologiczne aspekty porodów rodzinnych i ,tradycyjnych" - kierunki koncentracji świadomości rodzących. Klin Perinatol Ginekol. 2002; Supl 25:166-75.

27. Kowalska J, Olszowa D, Markowska D, et al. Aktywność fizyczna i szkoła rodzenia w czasie ciąży a poziom postrzeganego stresu i objawów depresyjnych u kobiet po porodzie. Psychiatr. Pol. 2014;48:889-900.

28. Gałuszka G, Gałuszka R, Ochwanowski P, Ochwanowska A. Wpływ ćwiczeń fizycznych na występowanie stanów depresyjnych u kobiet w połogu. Ann UMCS Sect D. 2005;60;5-8.

29. Craft LL. Exercise and clinical depression: examining two psychological mechanisms. Psychol Sport Exerc. 2005;6:151-71.

30. Zagórska A, Czopek A, Obniska J, Pawłowski M. Rola aktywności fizycznej w leczeniu depresji. Antropomotoryka. 2005;30:49-59.

31. Augustyniuk K, Rudnicki J, Grochans E, Jurczak A. Rola edukacji zdrowotnej i promocji zdrowia realizowanych w szkole matek w okresie adaptacji poporodowej. Piel Pol. 2007;2-3;217-20.

32. Augustyniuk K, Rudnicki J, Grochans E. Standard edukacji poporodowej realizowany w Szkole Matek i Ojców na oddziale neonatologicznopołożniczym. Perinatol Neonatol Ginekol. 2012;5:46-50.

33. Sioma-Markowska U, Poręba R. Analiza postawy ojców w porodzie rodzinnym w materiale Katedry i Oddziału Klinicznego Ginekologii i Położnictwa w Tychach Śląskiej Akademii Medycznej. Perinatol Neonatol Ginekol. 2008;1:141-48.

34. Ulman-Włodarz I, Poręba A, Kwiatkowska E, Szafarczyk A. Poród z udziałem ojca - wpływ na kształtowanie więzi w rodzinie. Klin Perin Gin. 2007;43:52-6.

35. Kaźmierczak M, Gebuza G, Gierszewska M. Zaburzenia emocjonalne okresu poporodowego. Probl Pielęg. 2010;18(4):503-11.

36. Ćwiek D. Ocena wpływu edukacji w szkołach rodzenia na przebieg ciąży, porodu i połogu oraz opiekę nad noworodkiem. Ann Acad Med Stetinesis. 2006;52:79-90.

37. Davim RMB, Torres GV, Dantas JC. Effectiveness of non-pharmacological strategies in relieving labor pain. Rev Esc Enferm USP. 2009;43:435-41.

38. Simkin P, O'Hara M. Nonpharmacologic relief of pain during labor: Systematic reviews of five methods. Am J Obstet Gynecol. 2002;186(Suppl.5):S131-59

39. Cendrowski K, Jaskólska M, Szałkowski A, et al. Ocena przebiegu porodu oraz stanu noworodka pacjentek po kursie w Szkole Rodzenia. Klin Perinatol Ginekol. 1996;Supl.XIII:111-6.

40. Cerańska-Goszczyńska H, Ciastoń-Przecławska E, Kmita G. Uczestnictwo w szkole rodzenia-jego wpływ na postawy wobec porodu i karmienia piersią. Klin Perinatol Ginekol. 1996;Supl.XIII:116-26. 
41. Ćwiek D, Torbe A, Gutowska-Czajka D, Czajka R. Rola Szkoły Rodzenia i Poradni Porodu Rodzinnego w przygotowaniu rodziców do porodu. Klin Perinatol Ginekol. 2002;Supl.25:147-54.

42. Maciejewski J, Niemiec T, Krawczyńska M, et al. Rola Szkoły Rodzenia w przygotowaniu do porodu w ocenie przyszłych rodziców. Klin Perinatol Ginekol. 2004;Supl.I:19-22.

43. Ziółkowska K, Banaszak A, Kamiński P. Wspólne uczestnictwo małżonków w porodzie - korzyści czy ryzyko? Klin Perinatol Ginekol. 2004;Suppl.I:90-3.

44. Brzozowska-Magoń A, Walicka-Cupryś K. Comparison analysis of readiness for labor, among women in Poland, Sweden and the USA. Moloda Sportivna Nauka Ukraïni. 2007;5:42-6.

45. Ćwiek D, Łuszczyńska V, Jurczak A, Augustyniuk K. Źródła wiedzy kobiet na temat zagadnień dotyczących ciąży i porodu. Wiad Lek. 2004;57(Suppl.1):52-58.

46. Grochans E, Łuczyńska V, Ćwiek D, Gorzkowicz B. Edukacyjna działalność szkoły rodzenia. Pielęg XXI w. 2003;4:69-73.

47. Deluga A, Olkuska E, Ślusarska B. Wiedza rodziców na temat okresu noworodkowego i ich oczekiwania wobec pielęgniarek i położnych. Med Og Nauk Zdr. 2012;18:281-6.

48. Lisius E, Michalik A: Uczestnictwo w zajęciach szkoły rodzenia jako forma psychoprofilaktyki. Położ Nauka Prakt. 2008;4:42-9.
49. Kossakowska-Petrycka K, Walęcka-Matyja K. Psychologiczne uwarunkowania wystąpienia depresji poporodowej u kobiet w ciąży o przebiegu prawidłowym i ciąży wysokiego ryzyka. Ginekol Pol. 2007;78:544-8.

50. Walentyn E, Wiktor A, Wdowiak A, et al. Opinie i obawy kobiet odnośnie porodu zależnie od przygotowania w szkole rodzenia. Zdr Publ. 2004;114:279-82

51. Bączyk G, Cebulska V, Koźlak V, et al. Poziom lęku przedporodowego u kobiet w ciąży. Probl Hig Epidemiol. 2011;92:774-7.

52. Soet JE, Brack GA, Dilorio C. Prevalence and predictors of women's experience of psychological trauma during childbirth. Birth. 2003;30:36-46.

53. Sadowska M, Kędzierska A, Wdowiak A, Brześcińska A. Efektywność funkcjonowania szkół rodzenia w opinii kobiet. EJMT. 2013;1:39-47.

54. Lee L, Holroyd E. Evaluating the effect of childbirth education class: a mixed-method study. Int Nurs Rev. 2009;56:361-8.

55. Jaddoe V. Antenatal education programs: do they work? The Lancet. 2009;374:863-4

56. Spinelli A, Baglio G, Donati S, et al. Do antenatal classes benefit the mother and her baby? J Matern Fetal Neonatal Med. 2003;13:94-101.

57. Kosińska K, Krychowska A, Wielgoś M, et al. Postawy ciężarnych wobec porodu - analiza form przygotowania i preferencji. Ginekol Pol. 2005;76:973-9.

\section{Corresponding author}

Grażyna Iwanowicz-Palus

Department of the Basics of Midwifery,

Faculty of Health Sciences, Medical University of Lublin,

4-6 Staszica Str., 20-081 Lublin

tel. 603234560

E-mail: spupalus@gmail.com 